\title{
FAKTOR RISIKO TERJADINYA KARIES BARU DENGAN PENDEKATAN KARIOGRAM PADA PASIEN ANAK DI KLINIK KEDOKTERAN GIGI ANAK RSGMP PROF. SOEDOMO YOGYAKARTA
}

\author{
Putri Kusuma Wardani M, AI Supartinah, Indah Titien S, SB Sri Rantinah, \\ Emut Lukito, Rinaldi Budi Utomo, dan Sri Kuswandari \\ Bagian IImu Kedokteran Gigi Anak, Fakultas Kedokteran Gigi Universitas Gadjah Mada, Yogyakarta
}

\begin{abstract}
ABSTRAK
Latar belakang. Faktor risiko karies adalah faktor yang berhubungan dengan kejadian karies pada individu dan populasi. Faktor risiko karies berbeda antar individu. Untuk menggambarkan interaksi antara faktor-faktor yang berhubungan dengan karies digunakan kariogram. Tujuan. Penelitian ini adalah untuk mendapatkan gambaran urutan faktor risiko karies dengan pendekatan kariogram pada pasien anak di klinik Kedokteran Gigi Anak RSGMP Prof. Soedomo. Metode. Subjek terdiri dari 26 anak dalam periode gigi-geligi bercampur. Dilakukan pemeriksaan tentang pengalaman karies, riwayat penyakit sistemik, frekuensi makan, skor plak, aktivitas Streptococcus mutans, volume sekresi saliva, $\mathrm{pH}$ saliva dan program fluoridasi. Hasil pemeriksaan dianalisis menggunakan program kariogram. Hasil. Penelitian menunjukkan bahwa rerata persentase faktor bakteri adalah $21,1 \%$, faktor pola makan: $18,1 \%$, faktor kerentanan gigi: $16,1 \%$ dan faktor lain-lain: $9,5 \%$. Kesimpulan. Dapat disimpulkan bahwa urutan faktor risiko karies dengan pendekatan kariogram adalah bakteri, pola makan, kerentanan gigi dan faktor lain-lain. Maj Ked Gi; Desemoer 2012; 19(2): 107-109
\end{abstract}

Kata kunci: karies, faktor risiko, kariogram

\section{ABSTRACT}

Background. Caries risk factor is factor related with caries insidence in individu and population. The caries risk factor is different between individu. For illustrating the interaction between caries related factors may be used cariogram. Aim. The aim of this research was to find out the sequence of caries risk factors from cariogram on children patients at the Clinic of Paediatric Dentistry Prof. Soedomo dental hospital. Method. Subjects were comprised 26 children in the periode of mixed dentition. Examinations were included: experience of caries, the history of systemic disease, daily meal frequency, plaque scoring, activity of Streptococcus mutans, the volume of saliva secretion, $\mathrm{pH}$ of saliva, and the participations of fluoridation program. The examinations result were analyzed with programme cariogram. Result. The result showed that the mean of percentage bacteria factor was $21,1 \%$, meal pattern factor: $18,1 \%$, susceptible teeth factor: $16,1 \%$ and others factors: $9,5 \%$. Conclusion. It could be concluded that the sequence of caries risk factors from cariogram were bacteria, meal pattern, susceptible teeth and others factors. Maj Ked Gi; Desember 2012; 19(2): 107-109

Key words: caries, risk factor, cariogram

\section{PENDAHULUAN}

Karies gigi dan gingivitis merupakan masalah utama dalam rongga mulut anak. Berbagai usaha pencegahan telah dilakukan tetapi kurang berhasil, terbukti sampai saat ini prevalensi penyakit tersebut masih cukup tinggi. Hasil penelitian menunjukkan jumlah anak yang terkena karies pada gigi desiduinya tercatat sebesar $85,17 \%{ }^{1}$

Karies gigi adalah suatu penyakit yang menyerang jaringan keras gigi yaitu email, dentin, dan sementum. Tanda terjadinya karies adalah adanya demineralisasi bagian anorganik gigi diikuti oleh kerusakan bahan organik. Proses demineralisasi terjadi karena adanya asam yang dihasilkan dari proses fermentasi karbohidrat oleh mikroorganisme. Untuk terjadinya karies perlu adanya faktor-faktor di dalam rongga mulut yang berinteraksi satu dengan yang lain. Faktor tersebut adalah host, mikroorganisme, substrat, dan waktu. ${ }^{2}$ Kapasitas masing-masing faktor dalam kejadian karies gigi berbeda antar perorangan maupun kelompok, karena struktur gigi, jenis bakteri yang dominan dalam rongga mulut, kualitas maupun kuantitas makanan dan waktu kontak bakteri dengan sisa makanan berbeda antar perorangan. ${ }^{3}$

Kariogram merupakan cara baru untuk menggambarkan interaksi berbagai faktor yang berperan dalam proses karies. Kariogram dikembangkan untuk membentuk pengertian yang lebih baik tentang aspek multifaktorial karies gigi dan sebagai penuntun dalam memperkirakan resiko karies. ${ }^{4}$

Klinik Kedokteran Gigi Anak RSGMP Prof. Soedomo FKG UGM melayani pasien anak dari daerah Yogyakarta dan sekitarnya. Jumlah pasien 
yang dirawat perbulannya rata-rata sekitar 500 orang. Kebanyakan dari pasien datang ke klinik dalam kondisi karies gigi yang parah.

Penelitian ini dilakukan untuk mendapatkan gambaran urutan faktor risiko terjadinya karies baru dengan pendekatan kariogram pada pasien anak di Klinik Kedokteran Gigi Anak RSGMP Prof. Soedomo. Dengan diketahuinya urutan faktor risiko terjadinya karies baru pada anak, dapat digunakan sebagai pedoman dalam perencanaan pencegahan karies gigi.

\section{METODE PENELITIAN}

Subjek penelitian adalah pasien anak periode gigi bercampur yang datang ke Klinik Kedokteran Gigi Anak RSGMP Prof. Soedomo. Penelitian dilakukan pada pasien yang dirawat selama bulan November 2011 dan satu pasien hanya dilakukan satu kali pemeriksaan kariogram.

Bahan penelitian yang digunakan adalah:

1) Disclosing solution untuk identifikasi plak;2) Cotton swab untuk mengoleskan Disclosing solution; 3) Cariostat untuk mengukur aktivitas bakteri; 4) Aquades steril; 5) Akohol; 6) Larutan saline dan 7) Pasta gigi.

Alat yang digunakan pada penelitian ini adalah:

1) Alat untuk mengukur volume saliva : gelas kecil, stopwatch, pipet ukur; 2) Alat diagnostik : pipet, sonde, ekstravator, kaca mulut; 3) $\mathrm{pH}$ meter untuk mengukur $\mathrm{pH}$ saliva ; 4) Program kariogram yang didesain oleh International Health Care Foundation, University Lund, Sweden; 5) Blangko kuesioner untuk survey diet.

Jalannya penelitian : Pada setiap subyek penelitian dilakukan pemeriksaan sebagai berikut : 1) Pengalaman karies, dinilai berdasarkan indeks deft / DMFT; 2) Riwayat penyakit-penyakit umum yang berhubungan dengan karies gigi; 3 ) Survey diet tentang frekuensi makan per 24 jam; 4) Banyaknya plak, diukur dengan indeks plak PHP-M; 5) Aktivitas Streptococcus mutans diukur dengan menggunakan Cariostat; 6) Volume sekresi saliva per menit tanpa stimulasi; 7) Derajat keasaman saliva; 8) Program fluoridasi.

Skor untuk setiap poin pemeriksaan di atas berkisar antara $0-3$. Semakin tinggi skor yang diperoleh keadaanya makin jelek. Data hasil pemeriksaan dianalisis menggunakan program kariogram yang didesain oleh International Health Care Foundation, University Lund, Sweden. Gambaran kariogram berupa diagram pie yang terbagi menjadi lima bagian sektor akan muncul setelah data dimasukkan (Gambar 1.).

Data yang diperoleh disajikan dalam persentase sesuai urutan besar faktor risiko terjadinya karies baru.

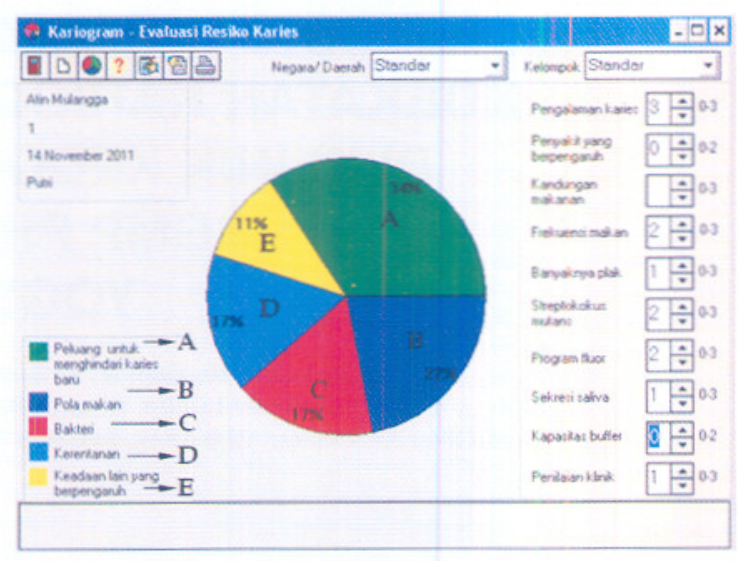

Gambar 1. Contoh Diagram Pie Kariogram

\section{HASIL PENELITIAN}

Hasil penelitian menunjukkan faktor bakteri merupakan faktor risiko terbesar untuk terjadinya karies baru, diikuti oleh pola makan, kerentanan gigi, kemudian faktor lain-lain (Tabel 1).

Tabel 1. Urutan Faktor Risiko Terjadinya Karies Baru

\begin{tabular}{clcc}
\hline No & Faktor Resiko & $\begin{array}{c}\text { Jumlah } \\
\text { Subjek } \\
(\mathrm{n})\end{array}$ & $\begin{array}{c}\text { Rerata } \\
\text { Persen- } \\
\text { tase }(\%)\end{array}$ \\
\hline 1 & Bakteri & 26 & 21,1 \\
\hline 2 & Pola makan & 26 & 18,1 \\
\hline 3 & Kerentanan gigi & 26 & 16,1 \\
\hline 4 & Faktor lain-lain & 26 & 9,5 \\
\hline
\end{tabular}

\section{PEMBAHASAN}

Berdasarkan rerata persentase hasil kariogram diperoleh pola urutan faktor risiko karies sebagai berikut: bakteri, pola makan, kerentanan gigi, dan faktor lain-lain. Bakteri merupakan faktor risiko karies terbesar pada subjek penelitian yaitu sebesar $21,1 \%$. Faktor ini merupakan kombinasi dari ba-nyaknya plak dan aktivitas Streptococcus muntans. Dalam penelitian ini, banyaknya plak diukur dengan indeks plak PHP-M. ${ }^{5}$ Dari 26 subyek, 15 subyek menunjukkan status kebersihan gigi dan mulut buruk. Seluruh subjek penelitian sedang dalam periode gigi bercampur, dengan rentang usia 5 tahun 9 bulan sampai 11 tahun 4 bulan. Menyikat gigi merupakan cara paling umum dalam pemeliharaan kebersihan gigi dan mulut. Sebagian besar anak usia 6-12 tahun kurang trampil dalam menyikat gigi. ${ }^{6}$ Pembersihan plak dari permukaan bukal sangat rendah dan kebanyakan anak hanya menyikat permukaan oklusal gigi. Sampai usia 10 tahun, anak-anak membutuhkan bantuan orang tua atau pengasuh dalam menyikat gigi. Plak merupakan penyebab karies, karena Streptococcus mutans dan bakteri penghasil asam lainnya dapat 
melekat pada permukaan gigi melalui media plak. ${ }^{7}$ Streptococcus mutans, Streptococcus sanguis, dan Streptococcus mitis merupakan mikroorganisme dengan persentase terbesar pada plak gigi. ${ }^{8}$ Streptococcus mutans merupakan mikroorganisme utama penyebab karies gigi dan berperan dalam mengawali kejadian karies. $^{9,} 10,11$ Hasil pengukuran aktivitas Streptococcus mutans dengan menggunakan cariostat menunjukkan 13 subyek memiliki aktivitas Streptococcus mutans sedang.

Urutan kedua faktor risiko karies dalam penelitian ini adalah pola makan. Dalam penelitian ini dilakukan survei diet untuk mengetahui frekuensi makan per 24 jam. Hasil survei menunjukkan 18 subjek frekuensi makannya 3 - 5 kali sehari, 5 subjek frekuensi makannya 6-7 kali sehari, dan 3 subjek frekuensi makannya lebih dari 7 kali seharí. Hubungan antara diet dan karies sudah banyak diteliti. Seluruh karbohidrat yang dapat difermentasikan oleh mikroorganisme memiliki potensi sebagai faktor risiko karies. ${ }^{11}$ Peningkatan frekuensi makan berhubungan dengan peningkatan karies gigi, terutama jika makanan yang dimakan diantara waktu makan mengandung gula yang mudah melekat pada gigi. ${ }^{9}$ Mengurangi frekuensi makan lebih penting dibanding mengurangi jumlah total karbohidrat. ${ }^{3}$

Kerentanan gigi merupakan faktor risiko karies urutan ketiga. Faktor ini merupakan kombinasi adanya program fluor, sekresi saliva, dan kapasitas bufer saliva. Program fluor yang diperoleh oleh seluruh subjek penelitian hanya penggunaan pasta gigi berfluor. Fluor secara luas digunakan untuk mencegah karies gigi. Pemberian fluor secara topikal dapat menghambat demineralisasi dan meningkatkan remineralisasi. ${ }^{10}$ Sekresi saliva pada penelitian ini diambil tanpa stimulasi. Tiga belas subjek menunjukkan volume sekresi saliva normal yaitu lebih dari $0,3 \mathrm{ml} /$ menit. Hanya satu subjek yang menunjukkan volume sekresi saliva rendah yaitu kurang dari $0,1 \mathrm{ml} /$ menit. Volume sekresi saliva kurang dari $0,1 \mathrm{ml} / \mathrm{menit}$ menunjukkan risiko karies. ${ }^{11}$ Hasil pengukuran $\mathrm{pH}$ saliva dari seluruh subjek penelitian menunjukkan $\mathrm{pH}$ saliva tinggi yaitu $\geq 6$. Hal ini berarti kapasitas bufer saliva subjek penelitian normal. Proses karies dikontrol oleh mekanisme proteksi alami yang terdapat pada saliva. ${ }^{9}$ Sekresi saliva berperan dalam pembersihan mekanis karbohidrat dan mikroorganisme. ${ }^{12}$ Saliva mengandung lysozyme yang dapat membunuh mikroorganisme, juga mengandung opsonin yang membuat mikroorganisme lebih rentan difagositosis oleh leukosit. Kapasitas bufer saliva berpengaruh pada proses karies. Efisiensi penetralan asam tergantung pada konsentrasi gula, frekuensi makan dan ketebalan plak.

Faktor risiko karies yang terakhir pada penelitian ini adalah faktor lain-lain. Faktor ini kombinasi dari pengalaman karies dan penyakit-penyakit umum yang berhubungan dengan karies. Dalam penelitian ini pengalaman karies dinilai berdasarkan indeks deft / DMFT. Hasil pemeriksaan menunjukkan bahwa 25 subjek memiliki tingkat keparahan karies tinggi dan hanya satu subyek memiliki tingkat keparahan karies sangat rendah. Faktor ini menempati urutan terakhir dalam penelitian karena meskipun hampir seluruh subyek tingkat kariesnya tinggi, tetapi seluruh subyek penelitian tidak memiliki riwayat penyakit umum yang berhubungan dengan karies gigi.

\section{KESIMPULAN}

Dari penelitian yang telah dilakukan terhadap 26 anak dalam periode gigi-geligi bercampur di Klinik Kedokteran Gigi Anak RSGMP Prof. Soedomo, dapat disimpulkan sebagai berikut: Urutan faktor risiko terjadinya karies baru dengan pendekatan kariogram adalah bakteri, pola makan, kerentanan gigi, dan terakhir faktor lain-lain

\section{DAFTAR PUSTAKA}

1. Suwelo IS: Karies Gigi Desidui dan Urutan Besar Peranan Faktor Resiko Terjadinya Karies, Disertasi FKG UGM, Yogyakarta, 1988: 99.

2. Kidd EAM \& Bechal SJ: Dasar-dasar Karies Penyakit dan Penanggulangannya (terj.), Cetakan kedua, ECG, Jakarta, 1992: 1-2.

3. Adair SM: Epidemiology and Mechanisms of Dental Disease, Dalam : Pinkham JR ed., Pediatric Dentistry Infancy Trough Adolescent, Saunders Comp., Tokyo, 1994:175-180.

4. Bratthal D, Petersson GH, \& Stjernsward JR: Cariogram Manual, 1997.Website: http://www.db.od.mah.se/car/ cariogram/cario graminfo.html. Diunduh pada $23 \mathrm{Mei}$ 2003.

5. Martens LV \& Meskin LH: An Innovative Technique for Assessing Oral Hygiene, J. Dent. for Children, 1972, January-February, 12-14.

6. Sandstrom A, Cressey J, \& Stecksen - Blicks C: Toothbrushing Behavior in 6-12 Year Old, Int. J. Paediatr. Dent, 2011, 21: 43-49.

7. Snawder KD: Handbook of Clinical Pedodontics, The C. V. Mosby Co., St. Louis, 1980: 63.

8. Michalek SM \& Mc. Ghee JR: Oral Streptococci with Emphasis on Streptococcus mutans, dalam Mc. Ghee JR dkk (ed): Dental Microbiology, Harper and Row Publishers, Philadelphia, 1982: 685.

9. Mc. Donald RE \& Avery DR: Dentistry for the Child and Adolescent, seventh Ed., Mosby - Year Book Inc., Toronto,2000: 210-239.

10. Cameron AC \& Widmer RP: Handbook of Pediatric Dentistry, Mosby-Wolfe, London, 1997: 55-56.

11. Koch G \& Poulsen S: Pediatric Dentistry - a Clinical Approach, Munksgaard, Copenhagen, 2001: 126-144.

12. Finn SB: Clinical Pedodontics, $4^{\text {th }}$. ed., W.B. Saunders Co., Philadelphia, 2003: 485-488. 